\title{
TECHNICAL MEETING
}

\author{
ANDI IRMAWATI PRATAMI \\ 9173770410149 \\ irmapratami01@gmail.com
}

1. Bentuk Kegiatan

$>$ Melakukan technical meeting mengenai lomba yang akan dilaksanakan.

2. Lokasi

$>$ Gasebo rumah kepala desa Bontocini.

3. Hari/Tanggal dan Waktu

> Senin, 19 oktober 2020 pukul 19:30 - selesai.

4. Peserta yang Dilibatkan

> Mahasiswa KKLP Yapti Jeneponto.

> Karang Taruna desa Bontocini

> Masyarakat setempat

5. Alasan Diadakannya

> Alasan diadakannya kegiatan ini adalah untuk memberitahukan mengenai ketentuan lomba kepada peserta lomba.

6. Tujuan dan Manfaat

> Tujuan dan Manfaatnya adalah untuk memperjelas mengenai peraturan-peraturan yang berlaku di dalam lomba nanti agar peserta tahu dan mengerti.

7. Deskripsi Kegiatan

> Kordes posko desa Bontocini membacakan beberapa rundown lomba yang berlaku. Setelah itu membuka sesi tanya jawab mengenai apa saja yang belum dimengerti oleh peserta lomba. 
